\title{
Trójkąty hamulcowe nowej generacji dla wagonów towarowych
}

\begin{abstract}
$W$ artykule przedstawiono nowa koncepcje trójkąta hamulcowego dla wagonów towarowych oraz wagonów towarowych dwuosiowych przystosowanych do prędkości $120 \mathrm{~km} / \mathrm{h} w$ stanie próżnym wagonu oraz $100 \mathrm{~km} / \mathrm{h} w$ stanie załadowanym wagonu, odpowiadajacym naciskowi zestawu kołowego na tor 22,5 t. Gtównym zatożeniem przy opracowaniu nowej konstrukcji było osiagnięcie minimalnej masy własnej przy zachowaniu własności wytrzymałości statycznej oraz zmęczeniowej, zwartość zabudowy, która umożliwia bezkolizyjna prace w standardowej konstrukcji ramy wózka rodziny Y25 oraz technologiczność konstrukcji. Artykut powstat w ramach realizacji projektu celowego $\mathrm{nr}$ ROW-III-056/2009 pt. ,, Trójkaty hamulcowe o optymalnej geometrii przestrzennej do zabudowy i eksploatacji w wózkach wagonów towarowych.", finansowanym przez Naczelna Organizacje Techniczna Stowarzyszeń Naukowo-Technicznych.
\end{abstract}

\section{WSTĘP}

Jednym $\mathrm{z}$ istotnych elementów układu hamulcowego wagonów towarowych czteroosiowych oraz dwuosiowych jest trójkąt hamulcowy. Rozwój jego konstrukcji jest związany $\mathrm{z}$ procesem standaryzacji dwuosiowych wózków wagonów towarowych, przeprowadzanych w ramach prac ORE/ERRI. Standaryzacja ta została zakończona uznaniem tych wózków przez UIC jako przystosowanych do ruchu międzynarodowego zgodnie z kartą UIC 432 [1]. Również przepisy TSI (ang.,,Technical Specifikation of Interoperability"), opracowane w ramach działalności Europejskiego Komitetu Normalizacyjnego (CEN- fr,„Comité Europeén de Normalistation") wyspecyfikowały typy wózków, które spełniają wymagania interoperacyjności [13]. Jedną $z$ rodzin wózków, które zostały dopuszczone do ruchu międzynarodowego jest rodzina wózków z zawieszeniem Y25, zgłoszona do standaryzacji przez koleje francuskie SNCF. Założenia prac standaryzacyjnych dla wózków wagonów towarowych zostały przedstawione $w$ raporcie ORE/ERRI B12/Rp.14/D [14]. Jednym z kryteriów podziału standaryzowanych wózków wagonów towarowych było wyposażenie hamulcowe, które było przystosowane albo do ruchu „S” albo do ruchu ,SS”. Miało to odzwierciedlenie w oznaczeniu międzynarodowym wózków, które zostało opracowywane w ramach Grupy Roboczej B12/4 „Wózki. Ogólne wymagania” (niem. „Drehgestelle. Allgemeine Fragen”), działającej w ramach ORE/ERRI. Wózki typu Y25Cs, Y25Rs, Y25Lsd1, Y25Lsd są przystosowane do ruchu „S”, natomiast wózki typu Y25Css, Y25Rss, Y25Ls(s)1 oraz Y25Ls(s) są przystosowane do ruchu „SS”. Jednym z elementów standaryzacji wózków jest trójkąt hamulcowy. W ramach reżimów hamulcowych „ruch S" oraz ruch „SS" powstały dwie odmiany trójkątów hamulcowych. Zasadnicza różnica pomiędzy dwoma odmianami trójkątów hamulcowych wynika $\mathrm{z}$ konieczności przeniesienia dwukrotnie większych sił przez trójkąty, które są przystosowane do ruchu „SS”. Obydwa trójkąty hamulcowe muszą jednak spełniać wymagania zamienności zgodnie z kartą UIC 542 [3] oraz tablicą 12 przepisów TSI [13]. Wymiary wraz tolerancjami oraz odchyłkami kształtu i położenia, które muszą być zachowane aby spełnić wymienność części są przedstawione na rys.1.

Tak więc karta UIC 542 [3], karta UIC 833[6] oraz PN-91/K-88176 [7] zastrzegaja jedynie wymiary oraz odchyłki kształtu i położenia, które musi spełniać konstrukcja trójkąta hamulcowego, aby była spełniona zasada „zamienności części”. Ostateczny kształt trójkąta oraz technologia wykonania są sprawą otwarta. Przyszła konstrukcja trójkąta powinna być zrealizowana w taki sposób, aby spełnić wymagania nieprzekraczania zarysu skrajni kinematycznej, który jest przedstawiony w karcie UIC 505-1 [2] oraz umożliwić montaż trójkąta tak, aby można było zagwarantować bezkolizyjność z innymi częściami na wózku podczas procesu hamowania $\mathrm{i}$ odhamowania (luzowania) hamulca. Dotyczy to zwłaszcza obsad z dwoma wstawkami dla trójkątów hamulcowych, które są zamontowane na ich czopach. W przypadku zużycia zestawów kołowych i maksymalnego ugięcia pionowego usprężynowania pierwszego stopnia dolna cześć obsady zbliża się do dolnego zarysu odniesienia skrajni kinematycznej. Jednym z istotnych problemów jaki powstał w ostatnich latach w dziedzinie kolejowych 


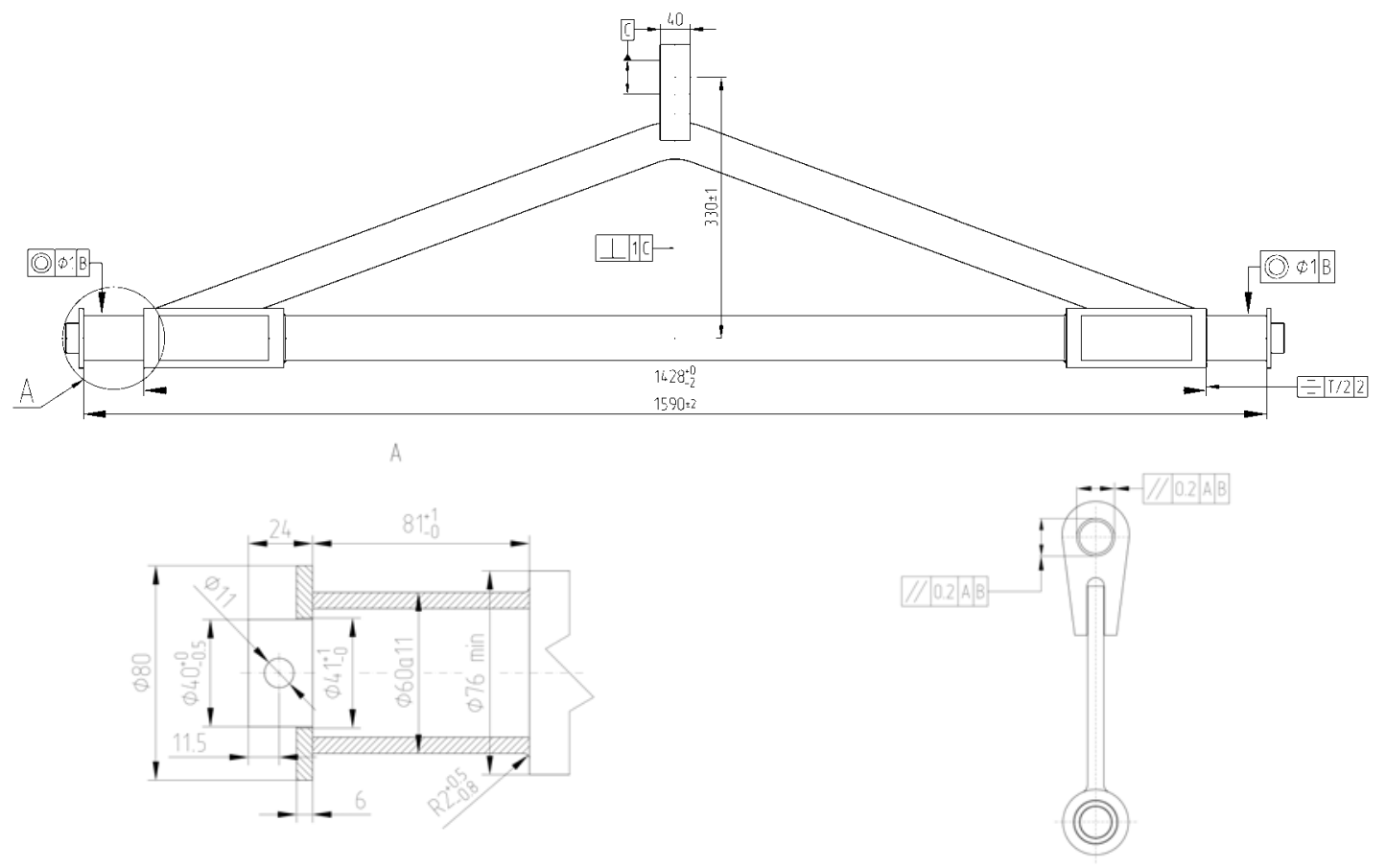

Rys.1. Wymiary wraz z przynależnymi odchyłkami kształtu i położenia, które muszą spełniać trójkąty hamulcowe do wagonów towarowych

przewozów towarowych jest kryterium masy własnej układu biegowego, który z kolei ma bezpośredni wpływ na ostateczną masę własną wagonu towarowego. Przy założonym, dopuszczalnym nacisku zestawu kołowego na tor zgodnie z kartą UIC 700 [4] ładowność zwiększa się przy ograniczeniu masy własnej wagonu towarowego, co zwiększa konkurencyjność kolejowych przewozów ładunków. Zaistniała sytuacja rynkowa zmusza konstruktorów oraz producentów do poszukiwania nowych „ultralekkich” rozwiązań trójkątów hamulcowych, które będą mogły być zastosowane w „ograniczonej” geometrii przestrzennej wózka oraz do stosowania takich technologii, które zagwarantują niskie koszty wytwarzania. W zaistniałej sytuacji rynkowej w kraju i zagranicą można zauważyć stały nacisk klienta na przemysł, aby obniżyć koszty zakupu, co wiąże się z koniecznością redukcji kosztów wytwarzania. Sytuację dodatkowo komplikuje fakt, że przy wprowadzaniu nowych konstrukcji trójkątów hamulcowych producent musi pokryć koszty badań typu oraz zainwestować w nowe oprzyrządowanie do produkcji masowej, aby zagwarantować wymagane tolerancje wymiarowe oraz odchyłki kształtu i położenia.

\section{WARUNKI PRACY TRÓJKĄTA 2.1. WYMAGANIA WYTRZYMALOŚCIOWE}

Trójkaty hamulcowe niezależnie od rodzaju ruchu „S"(,SS”) muszą być przystosowane do przeniesienia obciążeń wynikających z procesu hamowania nagłego, które jest realizowane podczas eksploatacji wagonów towarowych.

Konstrukcja trójkąta musi przenieść następujące obciążenia:

$>$ statyczne: nominalne oraz nadzwyczajne,

$>$ oraz zmęczeniowe.

Schemat obciążenia trójkąta hamulcowego jest przedstawiony na rys.2.

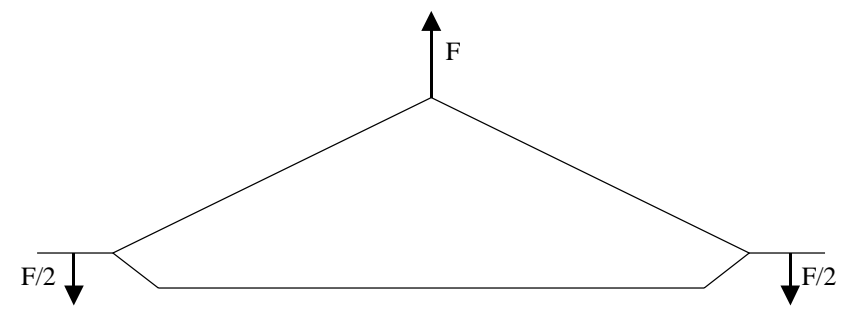

F- obciażenie przykładane w uchu trójkata hamulcowego F/2-reakcja przytożona na podporze trójkąta hamulcowego

Rys.2. Schemat obciążeń trójkąta hamulcowego siłami poziomymi

Zestawienie obciążeń, działających na trójkąt hamulcowy, przystosowany do ruchu „S” zgodnie z kartą UIC 833 [6] oraz PN-91/K-88176 [7]

Tabela 1

\begin{tabular}{|c|c|c|c|c|}
\hline L.p. & $\begin{array}{c}\text { Obciążenie wyj- } \\
\text { ściowe }[\mathbf{k N ]}\end{array}$ & $\begin{array}{c}\text { Obciążenie no- } \\
\text { minalne } \mathbf{F}_{\mathbf{n}}[\mathbf{k N}]\end{array}$ & $\begin{array}{c}\text { Obciążenie prób- } \\
\text { ne } \mathbf{F}_{\text {ep }}[\mathbf{k N}]\end{array}$ & $\begin{array}{c}\text { Obciążenie przy } \\
\text { próbie wytrzyma- } \\
\text { tości na zmęczenie } \\
{[\mathbf{k N ]}}\end{array}$ \\
\hline 1. & 5 & 60 & 90 & $10 \div 60$ \\
\hline
\end{tabular}


Dla zadanych obciążeń statycznych obowiązują dopuszczalne strzałki ugięcia, które są przedstawione $\mathrm{w}$ tabeli 2.

\section{Zestawienie dopuszczalnych odkształceń dla sil nominalnych i próbnych, dzialających na trójkąt hamulcowy do ruchu „S" zgodnie z karta UIC 833 [6] oraz PN-91/K-88176 [7]}

Tabela2

\begin{tabular}{|c|c|c|c|}
\hline $\begin{array}{c}\text { Rodzaj od- } \\
\text { ksztalcenia }\end{array}$ & $\begin{array}{c}\text { Odkształcenie } \\
{[\mathbf{m m}]}\end{array}$ & $\begin{array}{c}\text { Obciążenie no- } \\
\text { minalne } \mathbf{F}_{\mathbf{n}}[\mathbf{k N}]\end{array}$ & $\begin{array}{c}\text { Obciążenie } \\
\text { próbne } \mathbf{F}_{\mathbf{e p}}[\mathbf{k N}]\end{array}$ \\
\hline sprężyste & 2 & 60 & 0 \\
\hline trwałe & 0,1 & 60 & 0 \\
\hline sprężyste & 3 & 0 & 90 \\
\hline trwałe & 0,5 & 0 & 90 \\
\hline
\end{tabular}

Statyczne badania wytrzymałościowe trójkątów hamulcowych należy przeprowadzić zgodnie z PN-91/K88176 [7] oraz kartą UIC 833 [6]. Przebieg statycznych badań wytrzymałościowych jest przedstawiony na rys.3.

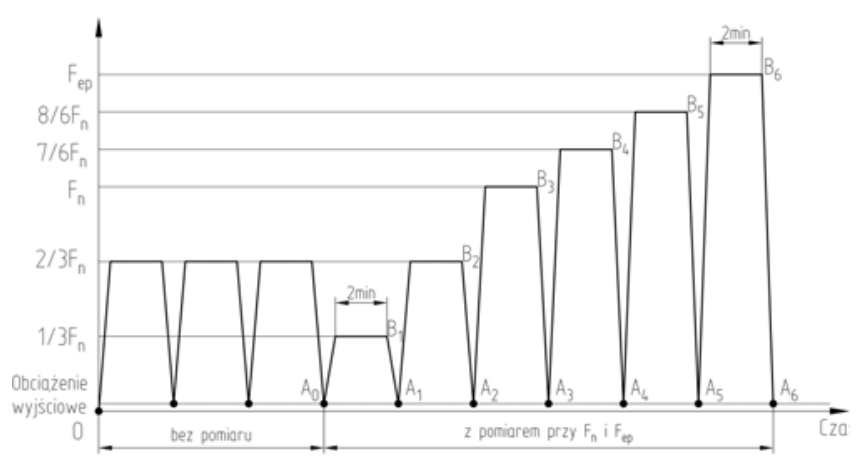

Rys.3. Przebieg statycznych badań wytrzymałościowych wg PN91/K-88176 [7] oraz karty UIC 833 [6]

Badany trójkąt hamulcowy należy umieścić w urządzeniu pomiarowym i poddać przez 2 minuty 3krotnie obciążeniu wstępnemu równemu $2 / 3$ obciążenia nominalnego $F_{n}$ wg tabeli 1 . Każdorazowo po 2 minutach obciążenia wstępnego jego wartość powinna być obniżona do wartości obciążenia wyjściowego wg tabeli 1 . Po trzykrotnym obciążeniu trójkąta hamulcowego obciążeniem wstępnym należy zmierzyć odległość $\mathrm{H}$, a następnie poddać trójkąt obciążeniom:1/3 $\mathrm{F}_{\mathrm{n}}, 2 / 3 \mathrm{~F}_{\mathrm{n}}, \mathrm{F}_{\mathrm{n}}, 7 / 6 \mathrm{~F}_{\mathrm{n}}, 8 / 6 \mathrm{~F}_{\mathrm{n}}$ oraz $\mathrm{F}_{\mathrm{ep}}$. Czas działania każdego obciążenia wynosi 2 minuty, przy czym przyłożenie poszczególnych obciążeń powinno być poprzedzone powrotem do obciążenia wyjściowego wg rys.3.

W czasie badania należy wykonać pomiary $\mathrm{H}$ dla każdej wartości obciążenia wstępnego i wyjściowego, a następnie określić:

$>$ odkształcenie sprężyste wywołane obciążeniem nominalnym $\mathrm{F}_{\mathrm{n}}$, równe różnicy wymiarów $\mathrm{H}$ w punkcie $\mathrm{B}_{3}$ i $\mathrm{A}_{3}$,

$>$ odkształcenie trwałe wywołane obciążeniem nominalnym $\mathrm{F}_{\mathrm{n}}$, równe różnicy wymiarów $\mathrm{H} \mathrm{w}$ punkcie $\mathrm{A}_{3}$ i $\mathrm{A}_{0}$, odkształcenie sprężyste wywołane obciążeniem próbnym $F_{n}$, równe różnicy wymiarów $H$ w punkcie $\mathrm{B}_{6}$ i $\mathrm{A}_{6}$,

$>$ odkształcenie trwałe, wywołane obciążeniem próbnym $\mathrm{F}_{\mathrm{ep}}$ równe różnicy wymiarów $\mathrm{H}$ w punkcie $\mathrm{A}_{6}$ i $\mathrm{A}_{0}$.

Wymiar $\mathrm{H}$ jest przedstawiony na rys.4.

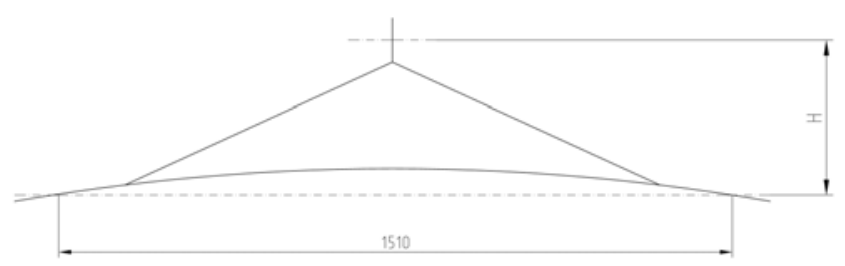

Rys.4. Wymiar H między osią ucha i wspólną osią czopów trójkąta hamulcowego przechodzącą przez ich środki

W celu dopuszczenia konstrukcji trójkąta hamulcowego do eksploatacji przeprowadza się badania statyczne i zmęczeniowe na stanowisku badawczym. Trójkąty hamulcowe poddaje się badaniom statycznym, przy czym bada się odkształcenia sprężyste i trwałe na 8miu sztukach prototypowych trójkątów hamulcowych. Przykłady stanowisk badawczych do badań statycznych są przedstawione na rys. $5 \div 8$ (warianty $\mathrm{I} \div \mathrm{IV}$ ).

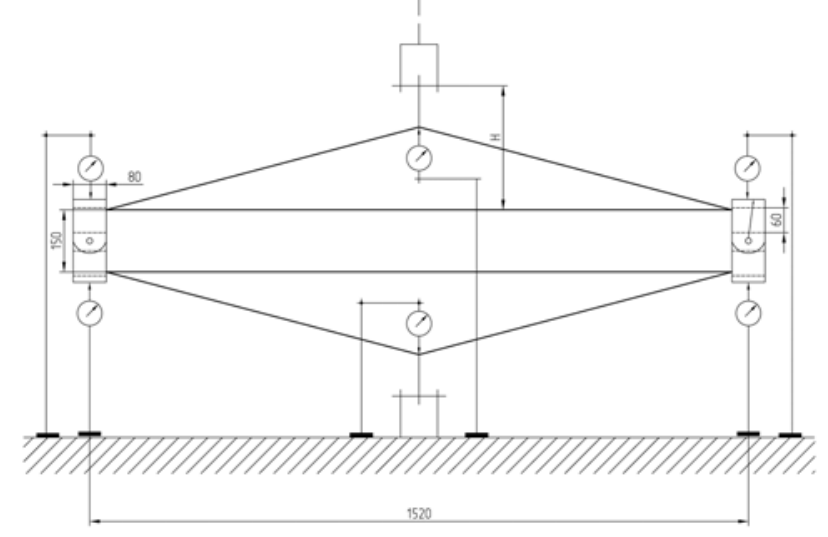

Rys.5. Przykład stanowiska do badań statycznych trójkąta hamulcowego-wariant I wg karty UIC 833 [6]

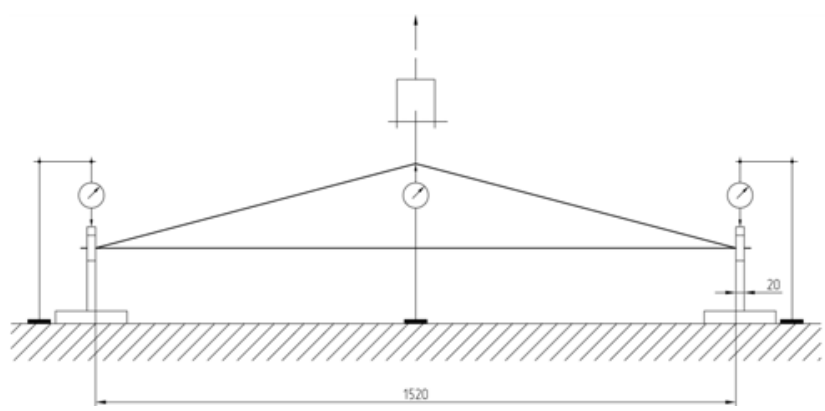

Rys.6. Przykład stanowiska do badań statycznych trójkąta hamulcowego- wariant II wg karty UIC 833 [6] 


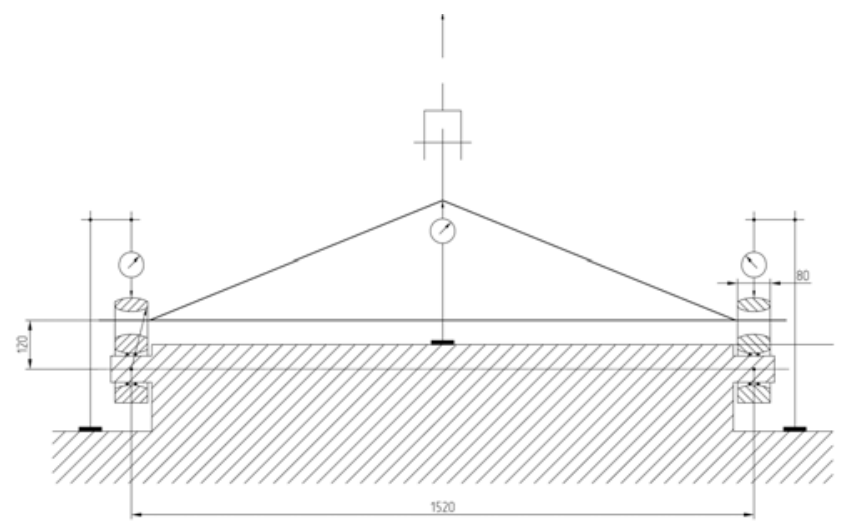

Rys.7. Przykład stanowiska do badań statycznych trójkąta hamulcowego- wariant III wg karty UIC 833 [6]

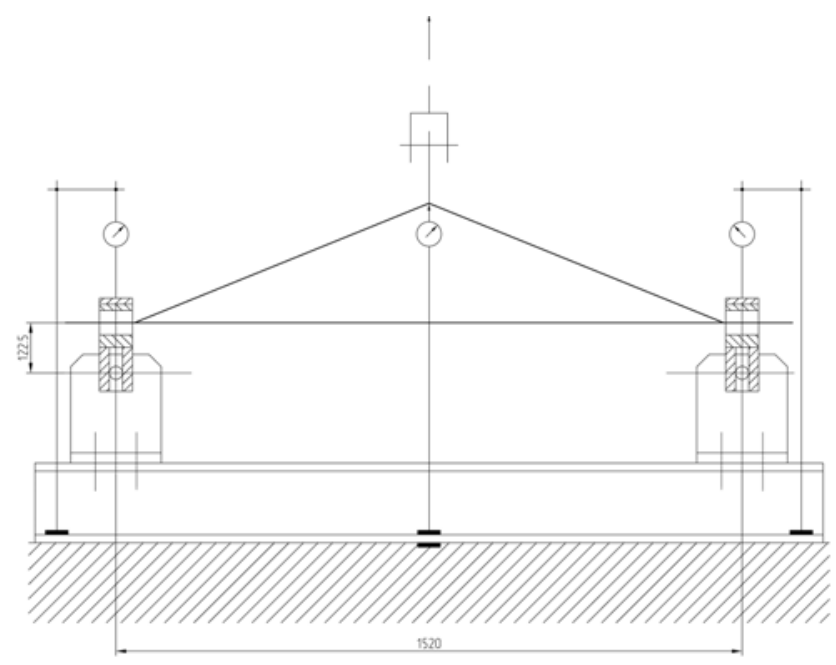

Rys.8. Przykład stanowiska do badań statycznych trójkąta hamulcowego- wariant IV wg karty UIC 833 [6]

$\mathrm{Na}$ dwóch dodatkowych trójkątach przeprowadza się stanowiskowe badania zmęczeniowe $\mathrm{z}$ częstotliwością przykładania obciążeń tętniących w zakresie $10 \div 60$ $\mathrm{kN}$, wynosząca $2 \div 16 \mathrm{~Hz}$. Próby zmęczeniowe uznaje się za pozytywne, jeśli nie wystapi żadne widoczne uszkodzenie trwałe ani też pękniecie, powodujące utratę nośności konstrukcji. Badania zmęczeniowe przeprowadza się na stanowisku stacjonarnym, które jest wyposażone w urządzenia do rejestracji częstotliwości oraz mogących mierzyć wartość chwilową przyłożonych obciążeń.

Tak więc kryteria wytrzymałościowe konstrukcji trójkąta hamulcowego sprowadzają się do:

$>$ zachowania dopuszczalnych strzałek ugięcia pod zadanymi obciążeniami $\mathrm{F}_{\mathrm{n}}$ i $\mathrm{F}_{\mathrm{p}}$ oraz

$>$ zachowania dopuszczalnych odkształceń trwałych pod obciążeniami $F_{n}$ i $F_{p}$,

$>$ takiego poziomu naprężeń $\mathrm{w}$ konstrukcji (wytężenia materiału), które pozwalają na przejście cyklu zmęczeniowego.

Ograniczenie dopuszczalnych strzałek ugięcia dla trójkątów hamulcowych wynika ze zdolności regulacyjnej nastawiacza klocków hamulcowych, który jest zainstalowany w układzie hamulcowym wagonu towarowego i który jest odpowiedzialny za utrzymanie skoku tłoka cylindra hamulcowego w trakcie eksploatacji.

Zdolność regulacyjna nastawiacza sprowadza się do kompensacji:

$>$ zużycia powierzchni tocznej koła,

$>$ zużycia wstawek klocków hamulcowych oraz

$>$ ugięć poszczególnych elementów (dźwigni, cięgien i trójkątów hamulcowych) przekładni hamulcowej.

W przypadku zakwalifikowania danej konstrukcji trójkąta hamulcowego do eksploatacji komercyjnej po zakończeniu badań ww. serii próbnej trójkąty hamulcowe po przeprowadzeniu prób statycznych można zabudować na wózkach wagonów towarowych, przeznaczonych do eksploatacji.

W przypadku trójkątów hamulcowych, poddanych badaniom zmęczeniowym i zakończonych $\mathrm{z}$ wynikiem pozytywnym obydwa egzemplarze należy złomować.

\subsection{WYMAGANIA PRZESTRZENI GEOME- TRYCZNEJ W PRZESTRZENI WÓZKA}

Trójkąt hamulcowy znajduje się w przestrzeni geometrycznej wózka, którą wynika z procesu hamowania i luzowania przekładni hamulcowej. Tę przestrzeń można określić jako przestrzeń roboczą dla trójkąta hamulcowego. Tym dwóm stanom towarzyszą procesy zużycia powierzchni tocznych kół oraz wstawek klocków hamulcowych.

Problem małej ilości miejsca dla trójkąta hamulcowego występuje zawsze na obydwu wózkach z obsadami z podwójnymi wstawkami ze strony skrajnej wagonu, gdzie są zastosowane tzw. „krótkie wieszaki” klocków hamulcowych o długości $225 \mathrm{~mm}$. W przypadku wózków Y25Lsd1 krytycznymi punktami konstrukcji są:

$>$ środkowa strefa czołownicy,

> wsporniki podłużnic, łączących belkę skrętową wózka $\mathrm{z}$ czołownicą i na których jest podwieszona przekładnia mechaniczna.

Problem ewentualnej kolizji jest tym większy im wyżej położony jest trójkąt a tym samym bliżej względem obydwu detali. Trójkąt hamulcowy jest położony wyżej przy zastosowaniu wieszaków o długości 225 $\mathrm{mm}$ dla wózków Y25Lsd1 $\mathrm{z}$ obsadami $\mathrm{z}$ dwoma wstawkami z żeliwa szarego wg karty UIC 832 [5] oraz z tworzywa sztucznego typu LL.

Zastosowanie „krótkich wieszaków” jest uzasadnione koniecznością uniknięcia kolizji między obsadami klocków hamulcowych z podwójnymi wstawkami z kółkami wciagarki, zastosowanej na górkach rozrządowych oraz koniecznością zastosowania płóz hamulcowych, które są wstawiane pod koła, celem unieruchomienia wagonu. Wciagarki są stosowane w celu wciagnięcia wagonu od ich podnóża na szczyt górki rozrządowej. Problem ten może pojawić się na skraj- 
nych tolerancjach wykonawczych, przy maksymalnie zużytych zestawach kołowych oraz z uwzględnieniem stanu ładownego i dynamiki pionowej nawet podczas przeprowadzania manewrów z małą prędkością.

W pozostałych częściach wózka (trzy trójkąty hamulcowe) zastosowane są wieszaki o długości 240 $\mathrm{mm}$ i tam problem ten nie występuje. Usytuowanie trójkąta hamulcowego z wieszakami o długości 240 $\mathrm{mm}$ w wózku typu Y25Lsd1 jest przedstawione na rys.9.

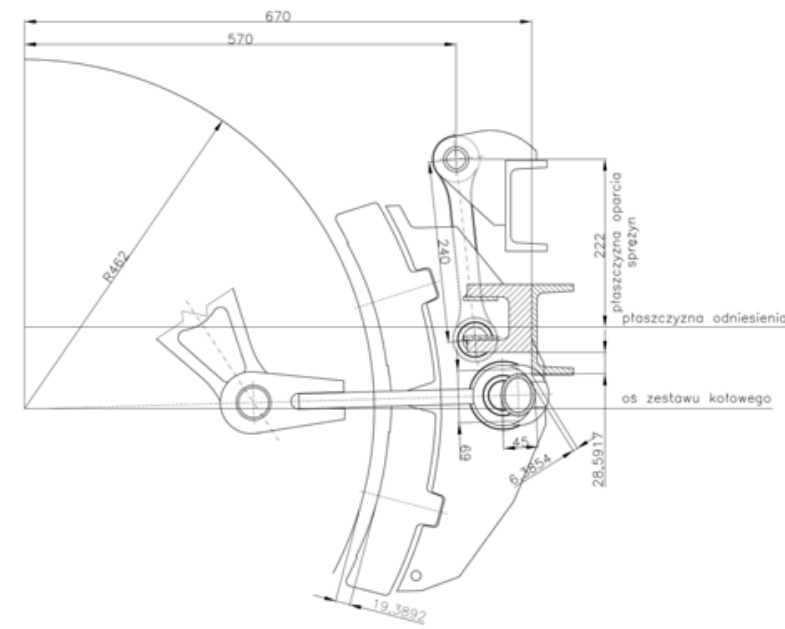

Rys.9. Usytuowanie trójkąta hamulcowego z wieszakami o długości $240 \mathrm{~mm}$ w wózku typu Y25Lsd1

W przypadku wózków $\mathrm{z}$ trójkątami $\mathrm{z}$ pojedynczą wstawką problem ten ma znaczenie mniejsze, gdyż w tego przypadku wózkach są zastosowane wieszaki o większej długości. Usytuowanie przykładowego trójkąta hamulcowego $\mathrm{z}$ wieszakami o długości $225 \mathrm{~mm}$ w wózku typu Y25Lsd1 jest przedstawione na rys.10.

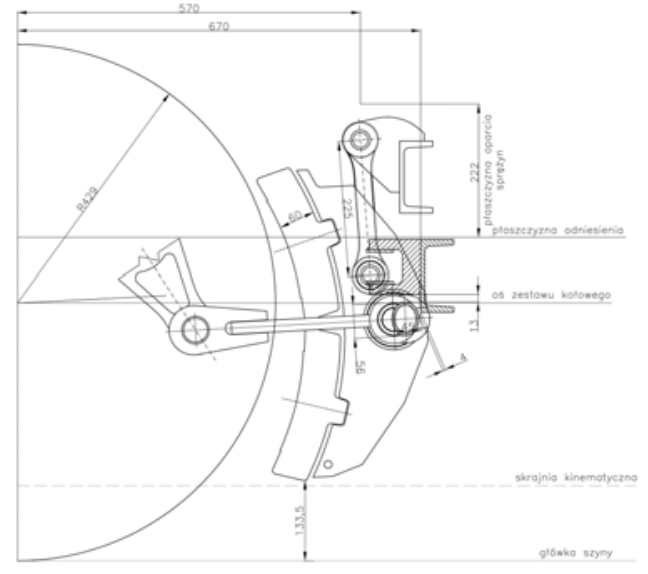

Rys.10. Usytuowanie trójkąta hamulcowego z wieszakami o długości $225 \mathrm{~mm}$ w wózku typu Y25Lsd1

$\mathrm{Z}$ analiz graficznych, przedstawionych na rys.9 i rys.10 każda konstrukcja trójkąta hamulcowego wymaga prawidłowego wykonania czołownicy ramy wózka, która jest wykonana z cewnika cienkościennego. Gięcie czołownicy jest przewidziane w dwóch płaszczyznach. Pierwsza płaszczyzna gięcia w kierunku wzdłużnym ma na celu zwiększenie przestrzeni roboczej dla trójkąta hamulcowego. Druga płaszczyzna gięcia w kierunku prostopadłym do poprzedniej ma na celu montaż cięgła łączącego układ mechaniczny na wózku z układem mechanicznym na nadwoziu wagonu towarowego oraz ewentualny montaż i demontaż sprzęgu automatycznego. Jak wynika z obecnej praktyki produkcyjnej i eksploatacyjnej gięcie czołownicy $\mathrm{w}$ dwóch płaszczyznach jest niezwykle trudną operacją. Nieprawidłowe jej przeprowadzenie powoduje ,paczenie” przekroju ceownika lub niedostateczne wygięcie w jednej z płaszczyzn. W przypadku „nadmiernego" wygięcia w płaszczyźnie prostopadłej do trójkąta hamulcowego podłużnice ramy zbliżają się do trójkąta hamulcowego. W przypadku niedostatecznego wygięcia w płaszczyźnie wzdłużnej trójkąt zbliża się do czołownicy. Tak więc warunkiem poprawnej pracy trójkąta hamulcowego jest prawidłowe wykonanie czołownicy. Najbardziej ograniczona przestrzeń robocza dla trójkąta hamulcowego występuje kiedy zamontowano nowe:

$>$ zestawy kołowe $\mathrm{z}$ odchyłka dodatnią na średnicy tocznej (tzn. $920^{+4} \mathrm{~mm}$ ) oraz

$>$ wstawki hamulcowe.

Przestrzeń ta powiększa się $\mathrm{w}$ miarę zużycia powierzchni tocznej koła oraz wstawki klocka hamulcowego.

\subsection{WYMAGANIA MASOWE I TECHNOLO- GICZNE}

Istotną cechą innowacyjną nowej konstrukcji trójkąta hamulcowego powinna być możliwie niska masa własna oraz technologiczność, która pozwoliłaby na obniżenie kosztów produkcji i zwiększyła jego konkurencyjność na rynku. Jedną $\mathrm{z}$ istotnych cech powinno być ograniczenie technologii spawania oraz maksymalne uproszczenie konstrukcji przy zachowaniu funkcjonalności i własności wytrzymałościowych przedstawionych $\mathrm{w}$ p.2.2. Przewiduje się, że proces spawania, jakość spoin, kwalifikacje spawaczy i odbiory prac spawalniczych będą odpowiadały wymaganiom grupy norm europejskich PN-EN 15085-2:2007

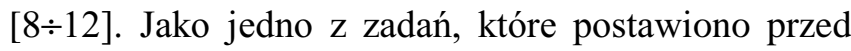
nową konstrukcją było osiagnięcie masy wynoszącej ok.30 kg. Uzyskanie takiej wartości, byłoby istotnym postępem w tym zakresie i trójkąt hamulcowy posiadałby najmniejszą masę spośród wszystkich stosowanych konstrukcji tego typu w Europie. Obniżenie masy własnej trójkąta powinno przyczynić się bezpośrednio do zmniejszenia materiałochłonności w produkcji seryjnej, co z kolei wpływa korzystnie na stronę ekonomiczną całego przedsięwzięcia. 
3. NOWE KONCEPCJE TRÓJKĄTÓW HAMULCOWYCH

Nowa koncepcja trójkątów hamulcowych opiera się na zastosowaniu w konstrukcji pięciu zasadniczych elementów którymi są:

$>$ ucho poz.1,

$>$ ramię poz.2 - płaskownik o przekroju $20 \times 40$ $\mathrm{mm}$,

$>$ czopy poz.3 - 2 sztuki,

$>$ łącznik poz.4 - rura o przekroju $\phi 51 \times 6,3 \mathrm{~mm}$,

$>$ tulejka poz.5.

Nowy trójkąt hamulcowy wraz z poz. $1 \div 5$ jest przedstawiony na rys.11.

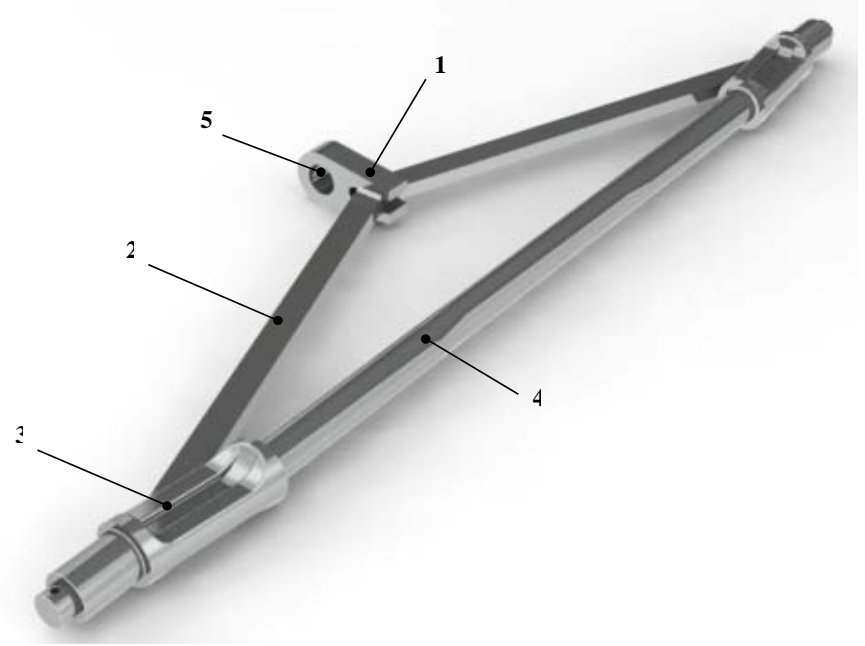

Rys.11. Trójkąt hamulcowy nowej generacji, przeznaczony do ruchu ,S”

Nowa koncepcja trójkąta hamulcowego polega na zastosowaniu ograniczonej ilości technologii spawania tzn. przy łączeniu ramienia $\mathrm{z}$ uchem oraz ramienia $\mathrm{z}$ czopami. Jak widać $\mathrm{z}$ rys. 11 czopy trójkątów hamulcowych poz. 3 posiadają wybrania materiałowe, w celu zmniejszenia masy trójkąta hamulcowego. Czopy te mogą być wykonane na potrzeby badań prototypowych drogą obróbki mechanicznej, natomiast w przypadku produkcji seryjnej jako odkuwki. W środku łącznika poz. 4 jest wykonany kształt eliptyczny $45 \times 56$ $\mathrm{mm}$ celem zwiększenia luzu pomiędzy czołownicą a trójkątem hamulcowym. Kształt przewężenia oraz luz pomiędzy czołownicą oraz trójkątem hamulcowym jest przedstawiony na rys.3. Na wykonanie wszystkich elementów jest przewidziana stal S355 J2, posiadająca dobre własności wytrzymałościowe oraz spawalność. Obliczenia wytrzymałościowe wykonano metodą elementów skończonych. Otrzymane wyniki obliczeń przedstawiono w postaci rozkładu:

$>$ naprężeń zredukowanych wg hipotezy HuberaMisesa,

$>$ naprężeń kierunkowych wzdłuż osi rury,

$>$ odkształceń trójkąta w kierunku działania siły.
Graficzne wyniki obliczeń dla sił $\mathrm{F}=90 \mathrm{kN}$ przedstawiono na rys. 12 i rys.13, natomiast dla siły obciążającej $\mathrm{F}=60 \mathrm{kN}$ na rys. 14 i 15 .

Obliczenia wytrzymałościowe przeprowadzono również dla różnych wariantów rur, uwzględniając ich przewężenia eliptyczne w środkowej strefie:

$>$ wariant, ,a” z przewężeniem eliptycznym $69 \times 52$ $\mathrm{mm}$ (rura $\phi 60,3 \times 5 \mathrm{~mm}$ i płaskownik o przekroju $50 \times 20 \mathrm{~mm}$, stosunek głównych osi elipsy $1,32)$

$>$ wariant ,b” $\mathrm{z}$ przewężeniem eliptycznym $75,25 \times 44,44 \mathrm{~mm}$ (rura $\phi 60,3 \times 5 \mathrm{~mm}$ i płaskownik o przekroju $50 \times 20 \mathrm{~mm}$, stosunek głównych osi elipsy 1,69 )

$>$ wariant ,„c” z przewężeniem eliptycznym 78,82 $\times 40,44 \mathrm{~mm}$ (rura $\phi 60,3 \times 5 \mathrm{~mm}$ i plaskownik o przekroju $50 \times 20 \mathrm{~mm}$, stosunek głównych osi elipsy 1,94$)$

$>$ wariant, ,d" z przewężeniem eliptycznym $72 \times 45$ $\mathrm{mm}$ (rura $\phi 51 \times 6,3 \mathrm{~mm}$ i plaskownik o przekroju $50 \times 20 \mathrm{~mm}$, stosunek głównych osi elipsy 1,6 )

$>$ wariant, ,e” z przewężeniem eliptycznym 56×45 $\mathrm{mm}$ (rura $\phi 51 \times 6,3 \mathrm{~mm}$ i płaskownik o przekroju $40 \times 20 \mathrm{~mm}$, stosunek głównych osi elipsy $1,24)$.

Wyniki obliczeń naprężeń zredukowanych $\sigma_{\text {red }}$, naprężeń głównych $\sigma_{3}$ oraz ugięć na połączeniu,,rura przejście koła w elipsę” oraz na „połączeniu ucha z ramieniem” (uznanymi jako „miejsca krytyczne”) dla obciążeń $F_{n}=60 \mathrm{kN}$ oraz $F_{\text {ep }}=90 \mathrm{kN}$ są przedstawione odpowiednio $w$ tabeli 3 i 4 .

$\mathrm{Na}$ podstawie przedstawionych wyników obliczeń metodą elementów skończonych stwierdzono, że:

$>$ odkształcenia trójkąta $\mathrm{w}$ miarę zwiększania stosunku głównych osi elipsy w przewężeniu rury, tylko w niewielkim stopniu ulegają zmianie (tabela 3),

$>$ odkształcenie sprężyste trójkąta dla wszystkich rozpatrzonych wersji elipsy nie przekracza dopuszczalnej wartości $3 \mathrm{~mm}$ przy obciążeniu próbnym $90 \mathrm{kN}$ (tabela 3) i $2 \mathrm{~mm}$ przy obciążeniu 60 $\mathrm{kN}$ (tabela 4),

$>_{\mathrm{w}}$ miarę zwiększania stosunku głównych osi elipsy wzrastają także naprężenia, przy czym największe ich wartości występują na przejściu rury $\mathrm{z}$ przekroju kołowego w elipsę,

$>_{\mathrm{o}}$ ile naprężenia zredukowane dla rury $\mathrm{z}$ elipsą 78,82 i 40,44 mm nie przekraczaja jeszcze granicy plastyczności materiału dla stali S355J2 (338 $\mathrm{MPa}<\mathrm{R}_{\mathrm{e}}=355 \mathrm{MPa}$ ), to naprężenia kierunkowe są już powyżej granicy plastyczności,

$>$ dla trójkąta z rurą o elipsie z osiami 75,25 i 44,44 mm (wersja b i d) oba warunki wytrzymałości sa spełnione zarówno dla przypadku obciążenia nominalną siłą rozciagającą $F_{n}=60 \mathrm{kN}$ jak i obciążeniem próbnym $\mathrm{F}_{\mathrm{ep}}=90 \mathrm{kN}$. 


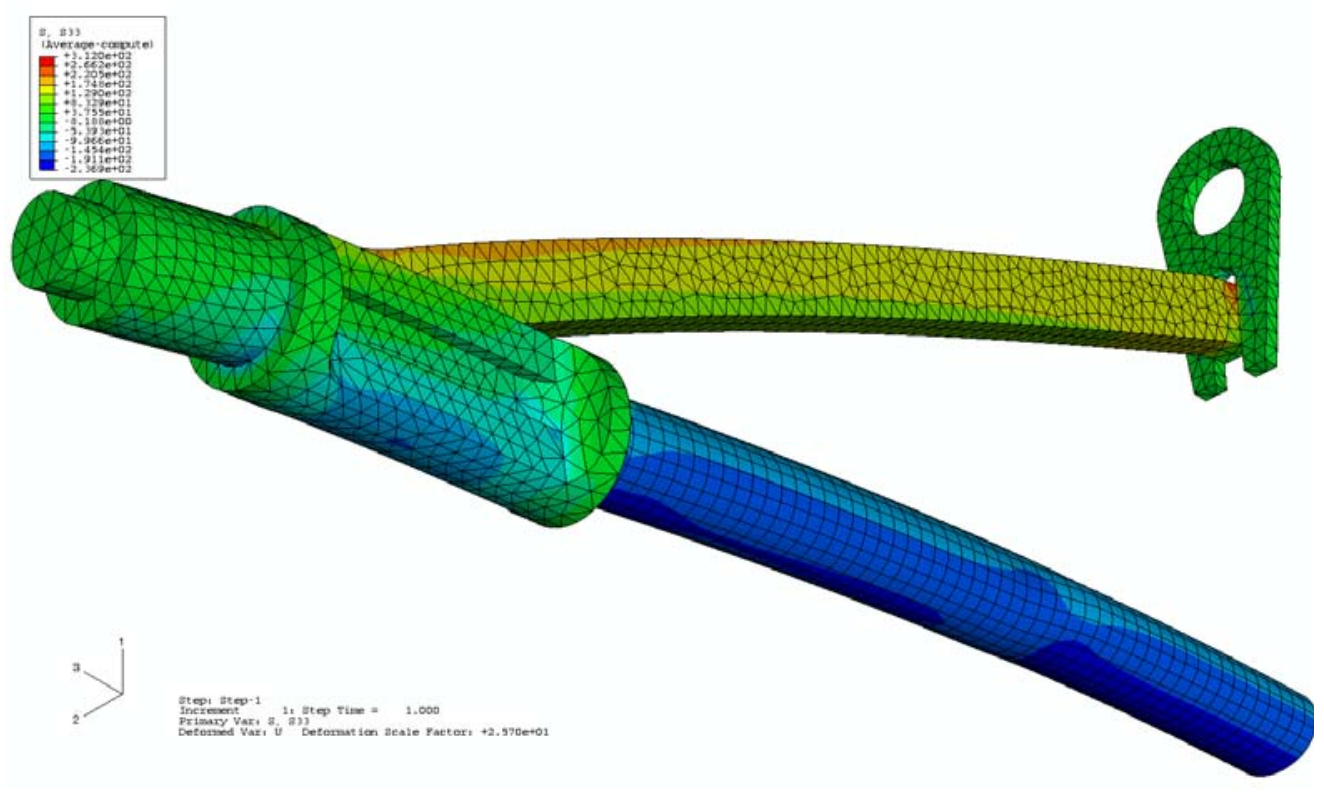

Rys.12. Rozkład naprężeń w kierunku osi ,z” (3) dla przypadku obciążenia siłą $\mathrm{F}_{\mathrm{ep}}=90$ $\mathrm{kN}$ trójkąta hamulcowego $\mathrm{z}$ rurą o przewężeniu elipsy $56 \mathrm{i}$ $45 \mathrm{~mm}$

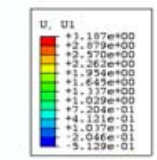

Rys.13. Rozkład odkształceń w kierunku działania siły $\mathrm{F}_{\mathrm{ep}}=90$ $\mathrm{kN}$ dla trójkąta hamulcowego $\mathrm{z}$ rurą o przewężeniu elipsy $56 \mathrm{i}$ $45 \mathrm{~mm}$

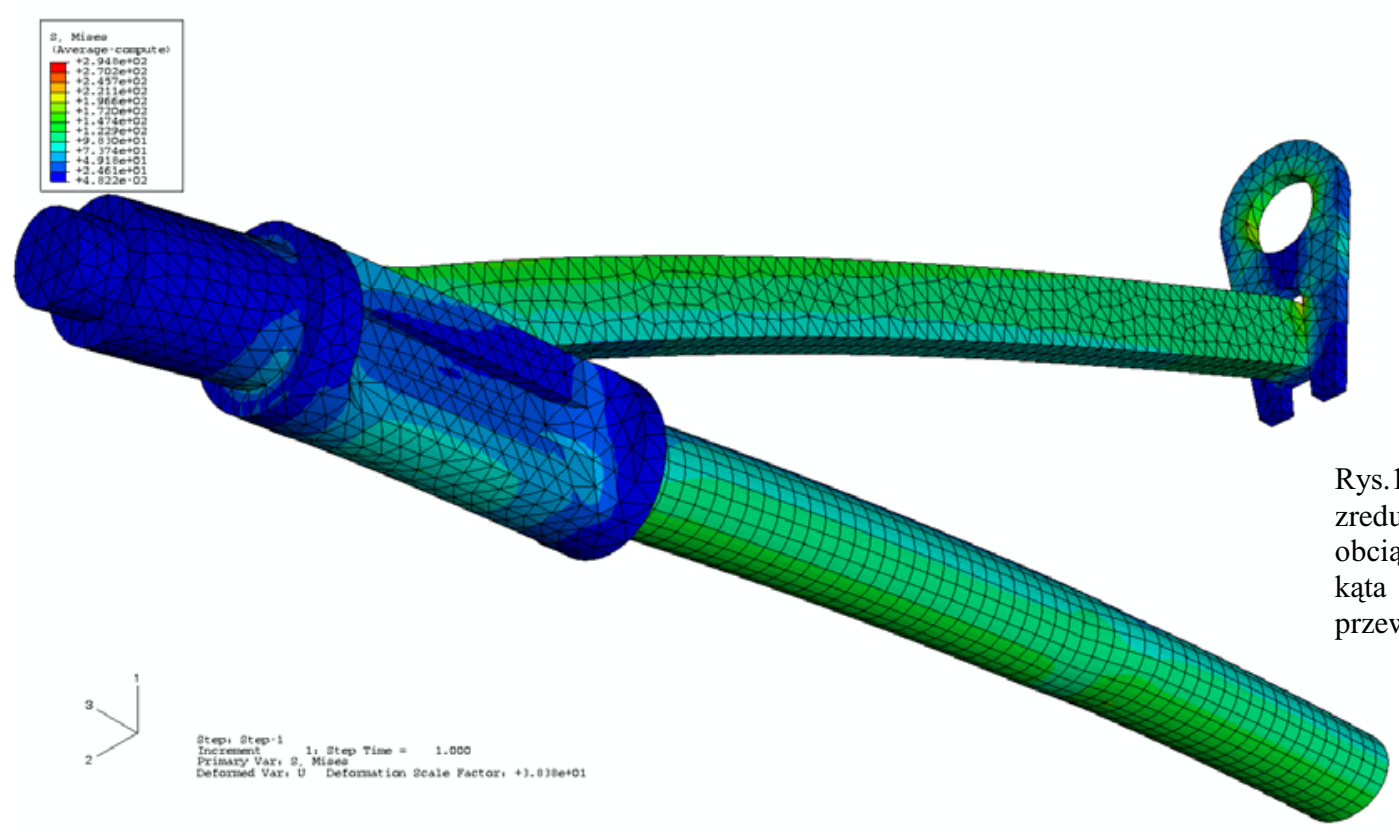




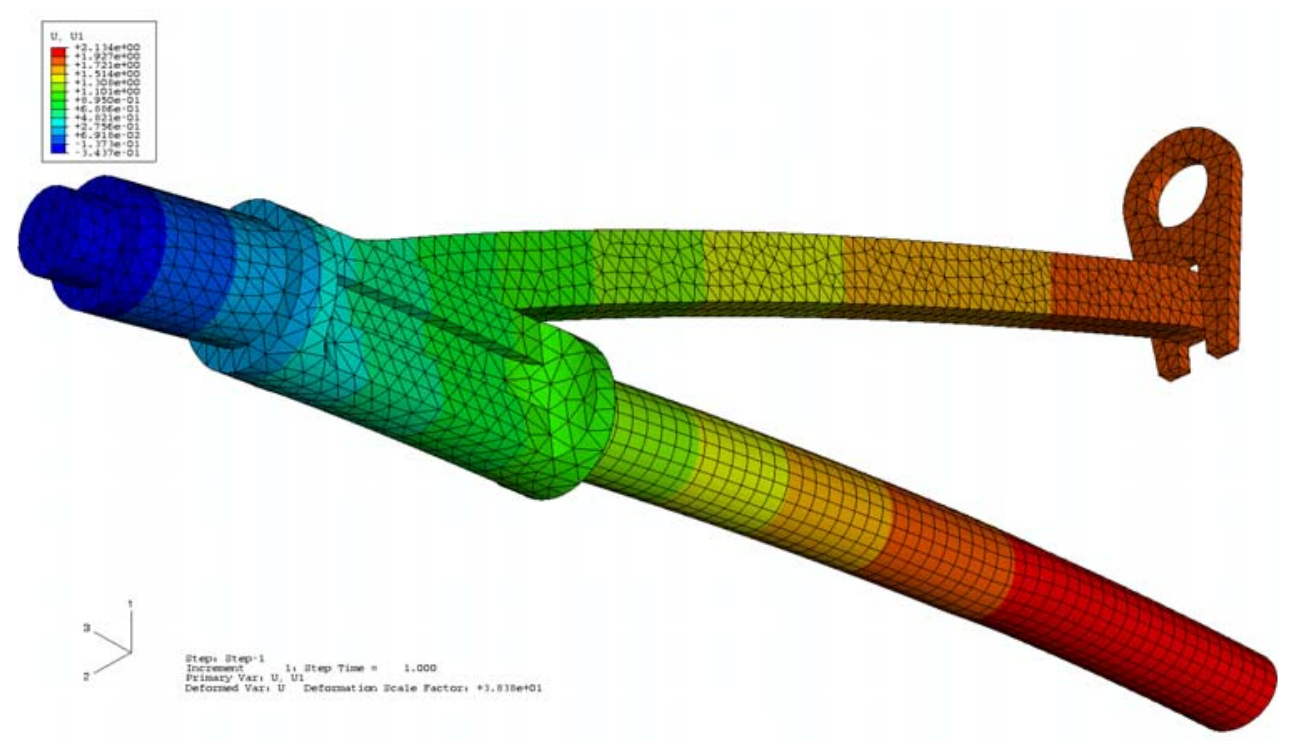

Rys.15. Rozkład odkształceń w kierunku działania siły $\mathrm{F}_{\mathrm{n}}=60$ $\mathrm{kN}$ dla trójkąta hamulcowego $\mathrm{z}$ rurą o przewężeniu elipsy $56 \mathrm{i}$ $45 \mathrm{~mm}$

Naprężenia zredukowane $\sigma_{\text {red }}$, naprężenia glówne $\sigma_{3}$ oraz strzalki ugięcia dla trójkąta hamulcowego w „wybranych miejscach krytycznych" dla obciążenia $F_{\mathrm{ep}}=90 \mathrm{kN}$

Tabela 3

\begin{tabular}{|c|c|c|c|c|c|c|}
\hline \multirow{2}{*}{ Miejsce konstrukcji } & \multirow{2}{*}{ wartość } & \multicolumn{5}{|c|}{ Wariant rury } \\
\hline & & $\mathbf{a}$ & b & c & d & e \\
\hline \multirow{2}{*}{$\begin{array}{l}\text { rura - przejście koła } \\
\text { w elipsę }\end{array}$} & $\sigma_{\text {red }}[\mathrm{MPa}]$ & 194 & 263 & 310 & 264 & 207 \\
\hline & $\sigma_{3}[\mathrm{MPa}]$ & -183 & -291 & -330 & -287 & -191 \\
\hline \multirow{2}{*}{$\begin{array}{l}\text { połączenie ucha z } \\
\text { ramieniem }\end{array}$} & $\sigma_{\text {red }}[\mathrm{MPa}$ & 158 & 144 & 170 & 144 & 355 \\
\hline & $\sigma_{3}[\mathrm{MPa}]$ & 138 & 127 & 132 & 136 & 266 \\
\hline ugięcie & $\mathrm{f} \quad[\mathrm{mm}]$ & 2,4 & 2,4 & 2,4 & 2,4 & 2,6 \\
\hline
\end{tabular}

Naprężenia zredukowane $\sigma_{\text {red }}$, naprężenia główne $\sigma_{3}$ oraz strzałki ugięcia dla trójkąta hamulcowego w „wybranych miejscach krytycznych" dla obciążenia $F_{n}=60 \mathrm{kN}$

Tabela 4

\begin{tabular}{|c|c|c|c|c|}
\hline \multirow{2}{*}{ Miejsce konstrukcji } & \multirow{2}{*}{ Oznaczenie } & \multirow{2}{*}{ Jednostka } & \multicolumn{2}{|c|}{ Wariant rury } \\
\cline { 4 - 5 } & & & b & e \\
\hline $\begin{array}{l}\text { rura - przejście koła } \\
\text { w elipsę }\end{array}$ & $\sigma_{\text {red }}$ & {$[\mathrm{MPa}]$} & 176 & 122 \\
\cline { 2 - 5 } & $\sigma_{3}$ & {$[\mathrm{MPa}]$} & -194 & -128 \\
\hline \multirow{2}{*}{$\begin{array}{l}\text { połączenie ucha } z \\
\text { ramieniem }\end{array}$} & $\sigma_{\text {red }}$ & {$[\mathrm{MPa}]$} & 112 & 197 \\
\cline { 2 - 5 } & $\sigma_{3}$ & {$[\mathrm{MPa}]$} & 91 & 147 \\
\cline { 2 - 5 } & $\sigma_{\max }$ & {$[\mathrm{MPa}]$} & 144 & 285 \\
\hline ugięcie & $\mathrm{f}$ & {$[\mathrm{mm}]$} & 1,6 & 1,7 \\
\hline
\end{tabular}

Bilans masowy trójkąta hamulcowego wg rys.4 z podziałem na części

Tabela 5

\begin{tabular}{|c|c|c|c|c|c|}
\hline część & lącznik & ramię & ucho & czopy & tulejka \\
\hline masa $[\mathrm{kg}]$ & 7,32 & 7,95 & 2,44 & 6,15 & 0,18 \\
\hline ilość sztuk & 1 & 1 & 1 & 2 & 1 \\
\hline masa cał.[kg] & 7,32 & 7,95 & 2,44 & 12,30 & 0,18 \\
\hline $\begin{array}{c}\text { masa trójkąta } \\
\text { [kg] }\end{array}$ & \multicolumn{5}{|l}{30,19} \\
\hline
\end{tabular}

Bilans masowy trójkąta hamulcowego z nowym ksztaltem ucha

Tabela 6

\begin{tabular}{|c|c|c|c|c|c|}
\hline część & lącznik & ramię & ucho & czopy & tulejka \\
\hline masa [kg] & 7,32 & 7,95 & 1,66 & 6,15 & 0,18 \\
\hline ilość sztuk & 1 & 1 & 1 & 2 & 1 \\
\hline $\begin{array}{c}\text { masa } \\
\text { całkowita [kg] }\end{array}$ & 7,32 & 7,95 & 1,66 & 12,30 & 0,18 \\
\hline masa trójkąta [kg] & \multicolumn{5}{|l}{} \\
\hline
\end{tabular}


$\mathrm{Z}$ tego względu przyjęto, że trójkąt $\mathrm{z}$ przewężeniem rury $\mathrm{w}$ elipsę o wymiarach zewnętrznych osi głównych 75,25 i 44,44 mm (wersja b) jest rozwiązaniem w którym występuje największe zwężenie elipsy a kryteria wytrzymałości są spełnione. Drugim miejscem konstrukcji trójkąta w którym występują duże wartości naprężeń jest połączenie ucha $\mathrm{z}$ ramieniem. $\mathrm{O}$ ile dla wersji trójkąta $\mathrm{z}$ rurą $\phi 60,3 \times 5 \mathrm{~mm}$ i ramieniem o przekroju 50x20 mm poziom naprężeń w tym miejscu nie przekracza $200 \mathrm{MPa}$ to dla wersji $\mathrm{z}$ rura $\phi$ $51 \times 6,3 \mathrm{~mm}$ i ramieniem o przekroju 40x20 $\mathrm{mm}$ dla przypadku obciążenia siłą $\mathrm{F}_{\mathrm{ep}}=90 \mathrm{kN}$ naprężenia osiągają poziom granicy wytrzymałości materiału.

Bilans masowy nowego trójkąta jest przedstawiony w tabeli 5 .

Jak widać z przedstawionego bilansu masa trójkąta hamulcowego wynosząca $30 \mathrm{~kg}$ może być osiagnięta w produkcji seryjnej. Bilans masowy został oparty na wymiarach nominalnych oraz przy założeniu, że masy spoin nie uwzględnia się. Ponieważ masa trójkąta hamulcowego nieznacznie przekracza $30 \mathrm{~kg}$ szukano dalszych „oszczędności masowych” tak, aby przy skojarzeniu niekorzystnych odchyłek wymiarowych zadeklarowana masa trójkąta $30 \mathrm{~kg}$ nie została przekroczona. Ewentualne korzyści masowe znaleziono w uchu trójkąta hamulcowego, które zostało bardziej „wyprofilowane”. Nowy kształt ucha może być wykonywany droga „obróbki mechanicznej” (przygotowanie prototypów do badań), drogą „wypalania” lub kucia (dla produkcji seryjnej). Konstrukcja trójkąta hamulcowego z nowym kształtem ucha jest pokazana na rys.16.

Bilans masowy trójkąta hamulcowego $\mathrm{z}$ nowym kształtem ucha jest przedstawiony w tabeli 6 .

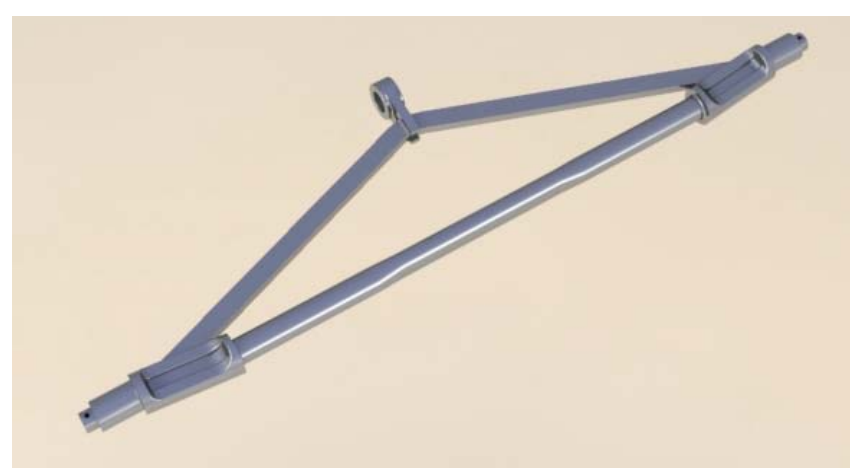

Rys.16. Konstrukcja trójkąta hamulcowego z nowym kształtem ucha

Jak widać z przedstawionego bilansu w tabeli 6 masa trójkąta hamulcowego wynosi $29,41 \mathrm{~kg}$. Z wstępnych obliczeń wytrzymałościowych wynika, że taki wariant spełnia wymagania $\mathrm{w}$ zakresie wytrzymałości statycznej i zmęczeniowej.

\section{WNIOSKI}

Z przedstawionej analizy wynika, że jest możliwe skonstruowanie „ultralekkiego trójkąta hamulcowego" przeznaczonego dla ruchu ,S” o masie ok.30 kg. Konstrukcja taka spełnia wymagania przestrzennej zabudowy w wózkach typu Y25Lsd1. Spełnia również dodatkowo wymagania przestrzeni roboczej, wynikającej z procesu „hamowania” i „luzowania” mechanicznej przekładni hamulcowej. Jak dowiodły obliczenia wytrzymałościowe, przeprowadzone metodą elementów skończonych spełnione są wymagania dotyczące wytrzymałości statycznej i zmęczeniowej. W przypadku wytrzymałości statycznej spełnione są kryteria, dotyczące dopuszczalnej strzałki ugięcia, odkształceń trwałych dla sił obciążających 60 i 90 kN, wynikających $z$ hamowania nagłego. $Z$ wyznaczonego poziomu naprężeń metodą elementów skończonych wynika, że jest możliwe również przejście testu zmęczeniowego na poziomie $10^{7}$ cykli obciążeń zgodnie z wymaganiami karty UIC 833 [6] oraz PN-91/K-88176 [7]. W celu potwierdzenia ww. wniosków jest konieczne przeprowadzenie badań pełnych na trójkątach prototypowych. Poszukiwanie ultralekkich konstrukcji przyczynia się do zwiększenia konkurencyjności transportu towarowego na rynku przewozowym ładunków. Bezpośrednią przyczyną zmniejszenia masy trójkąta hamulcowego jest konieczność ograniczenia masy układów biegowych i zwiększenia ładowności wagonów towarowych. W przypadku ograniczenia masy wagonu towarowego zwiększa się więc efektywność przewozową, zarówno w stanie próżnym oraz ładownym. Dzięki coraz powszechniejszemu wprowadzaniu wstawek typu „K” z tworzyw sztucznych o bardzo wysokim współczynniku tarcia i gwarantującym niski poziom emisji hałasu do środowiska naturalnego podczas przejazdu wagonów towarowych jest możliwość zrealizowania ruchu „SS” dla trójkąta hamulcowego o nośności $60 \mathrm{kN}$. Wariant ten jest całkowicie realny w przypadku produkcji nowych wagonów towarowych. Jest to kolejny argument za podjęciem prac studialnych, konstrukcyjnych oraz wdrożeniowych do produkcji seryjnej w przemyśle krajowym.

\section{Literatura}

[1] Karta UIC 432: Wagony towarowe. Prędkości jazdy. Warunki techniczne, które należy spetnić. 11-te wydanie z września 2006.

[2] Karta UIC 505-1: Pojazdy kolejowe. Skrajnia pojazdów. 10-te wydanie z maja 2006

[3] Karta UIC 542: Części hamulcowe. Wymienność. 4te wydanie z 1.0.1982 ze zmianq z dnia 1.01.1995 oraz errata $z$ dnia 1.01.1997.

[4] Karta UIC 700: Klasyfikacja linii kolejowych. Przynależne granice obciqżania wagonów towarowych. 10-te wydanie z 11.2004. 
[5] Karta UIC 832: Warunki techniczne dostawy wstawek klocków hamulcowych z żeliwa fosforowego dla pojazdów trakcyjnych $i$ wagonów. 3-cie wydanie $z$ 01.2004.

[6] Karta UIC 833: Warunki techniczne na dostawe trójkatów hamulcowych. 3-cie wydanie z luty 2004.

[7] PN-91/K-88176: Wagony towarowe. Trójkaty hamulcowe.

[8] PN-EN 15085-1:2007: Kolejnictwo. Spawanie pojazdów szynowych i ich części składowych. Część 1: Postanowienia ogólne.

[9] PN-EN 15085-2:2007:Kolejnictwo. Spawanie pojazdów szynowych i ich części składowych. Część 2: Wymagania dotyczqce jakości i certyfikacja zakładów spawalniczych.

[10] PN-EN 15085-3:2007: Kolejnictwo. Spawanie pojazdów szynowych i ich części składowych. Część 3: Wymagania konstrukcyjne.
[11] PN-EN 15085-4:200: Kolejnictwo. Spawanie pojazdów szynowych i ich części składowych. Część 4:2007 Wymagania produkcyjne.

[12] PN-EN 15085-5:2007: Kolejnictwo. Spawanie pojazdów szynowych i ich części składowych. Część 5: Kontrola, badania i dokumentacja

[13] Przepisy TSI: Decyzja komisji dotyczaca specyfikacji interoperacyjności odnoszacej się do podsystemu „tabor kolejowy-wagony towarowe” transeuropejskiego systemu kolei konwencjonalnych z dnia 26 lipca 2006. Dziennik Urzędowy Unii Europejskiej.

[14] Raport ORE/ERRI B12/Rp.14/D Frage B12: Vereinheitlichung der Güterwagen. Bericht Nr.14. Utrecht, 11.1967. 